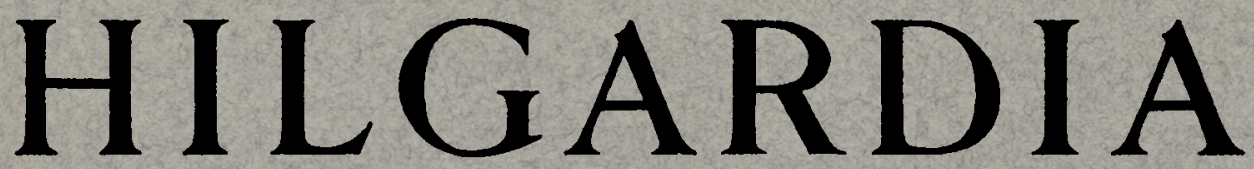

A Journal of Agricultural Science Published by the California Agricultural Experiment Station

ORNAMENTAL FLOWERING PLANTS

NATURALLY INFECTED WITH CURLY-TOP AND ASTER-YELLOWS VIRUSES

HENRY H. P. SEVERIN AND JULIUS H. FREITAG

\title{
WEED HOST RANGE AND \\ OVERWINTERING OF CURLY-TOP VIRUS
}

HENRY H. P. SEVERIN 


\section{$\begin{array}{lllllllll}\text { H } & \text { I } & \text { L } & G & \text { A } & \text { R } & \text { D } & \text { I } & \text { A }\end{array}$}

A Journal of Agricultural Science Published by

the California Agricultural Experiment Station

\begin{tabular}{lll} 
VoL. 8 & SEPTEMBER, 1934 & No. 8 \\
\hline
\end{tabular}

\section{ORNAMENTAL FLOWERING PLANTS \\ NATURALLY INFECTED WITH CURLY-TOP AND ASTER-YELLOWS VIRUSES ${ }^{1}$}

HENRY H. P. SEVERIN ${ }^{2}$ AND JULIUS H. FREITAG ${ }^{3}$

(Contribution from the Division of Entomology and Parasitology, College of Agriculture, University of California, coöperating with the United States Department of Agriculture, Bureau of Entomology.)

\section{INTRODUCTION}

A FEW OF THE virus DISEASES have been experimentally transmitted to many species of plants in different genera of many families. The host range of virus diseases as determined by experimental infection often does not coincide with the food and breeding plants preferred by the insect vector of the disease under natural conditions: preferred food and breeding plants of the insect under field conditions are sometimes immune to virus diseases; and the insect cannot live for more than a few days in captivity on some host plants that are highly susceptible to virus diseases in the natural environment. A review of the literature on the host range of certain virus diseases as determined by experimental and natural infection follows.

Kunkel $^{(8,9)}$ reported that he experimentally transmitted aster yellows with Cicadula divisa Uhl. to 170 species in 150 genera belonging to 38 families. He transmitted the disease to asters from 40 different species of plants experimentally infected with yellows. There is no record of the natural occurrence of yellows on most of the plants experimentally infected with the disease. Three methods were used by him in determining whether a plant was naturally infected with yellows. In the first method the virus was recovered by previously noninfective leafhoppers from the naturally infected plants and transferred to asters. He proved by this

1 Received for publication February 17, 1934.

2 Associate Entomologist in the Experiment Station.

3 Research Assistant in the Experiment Station. 
method that 9 species in 9 genera of 4 families were infected with yellows in the natural environment. In the second method a comparison was made of the symptoms on naturally and experimentally infected plants, but this method does not definitely prove that the disease observed on any yellowed plant is actually aster yellows. He records 12 species in 11 genera of 5 families with this method. The third method used was by grafting yellowed buds into healthy plants. This method was used with tomato plants. The virus was not transmitted to tomato by Cicadula divisa.

Priode $^{(11)}$ inoculated 20 different species of plants with the juice from tobacco plants infected with American ringspot and transmitted the disease to only 4 species in 4 genera of 3 families.

Wingard ${ }^{(22)}$ transmitted American ringspot disease of tobacco ( Nicotiana tabacum) to 62 species in 38 genera belonging to 17 families of plants with several methods of inoculation.

The natural host range of American ringspot includes a total of 11 species in 9 genera of 3 families as determined by Fromme and Wingard, (4) Wingard and Godkin, ${ }^{(23)}$ Wingard, ${ }^{(22)}$ Johnson, ${ }^{(7)}$ and Henderson. ${ }^{(5,6)}$

Bald and Samuel ${ }^{(1)}$ experimentally infected with spotted wilt, 35 species of plants in 15 genera belonging to 4 families. The virus was transmitted by the thrips, Frankliniella insularis, to 15 species of plants in 10 genera. The virus was recovered by previously noninfective thrips from 6 species of infected plants in 3 genera, and transferred to tomatoes. Thirty-four species in 15 genera were infected with the juice from infected tomatoes by mechanical inoculation. The virus was returned to tomatoes from 30 infected species in 15 genera by mechanical inoculation.

Smith $^{(19,20,21)}$ experimentally infected 28 species of plants in 13 genera belonging to 4 families with the virus of spotted wilt. The virus of spotted wilt in the British Isles is not identical with the virus of ringspot described by Wingard and others in the United States.

The natural host range of spotted wilt includes a total of 8 species in 8 genera belonging to 5 families as determined by Bald and Samuel ${ }^{(1)}$ and Smith. ${ }^{(21)}$

Severin and his coworkers ${ }^{(12,13,15,17,18)}$ reported that 166 species of plants, in 114 genera, belonging to 36 families were experimentally infected by the beet leafhopper, Eutettix tenellus (Baker). Fifty-three species of plants in 38 genera of 16 families were proved to be naturally infected with curly top. A total of 174 species of plants in 115 genera in 37 families were either experimentally infected or demonstrated to be naturally infected with curly top. The virus was recovered from the ex- 
perimentally or naturally infected plants by previously noninfective heet leafhoppers and transferred to sugar beets.

McKay ${ }^{(10)}$ found that zinnia and strawflower were susceptible to curly top under laboratory conditions and came to the conclusion, on circumstantial evidence, that these ornamental flowering plants were naturally infected with the disease. He reported that zinnia approached a failure at Pullman and strawflowers near Seattle, Washington, during 1926. Strawflower near Los Angeles has often been a failure, and curly top appears to be the cause.

Surveys were made from 1925 to 1933 to determine the injury to ornamental flowering plants in the San Juan, Salinas, San Joaquin, and Sacramento valleys. Field investigations were conducted on the ranches of seed companies, the University Farm at Davis, and nurseries where cut flowers were sold. An examination was also made of flower gardens in parks, around schools, hotels, and homes, and flowering plants grown in cemeteries. A study of the symptoms of the disease on ornamental flowering plants was undertaken in naturally and experimentally infected plants.

\section{Methods of Testing Plants Naturally Infected with Virus}

\section{Diseases}

Curly Top.-The methods of testing economic plants and weeds which were naturally infected with curly top have been described in a previous paper, ${ }^{(18)}$ but a few changes in methods were made with ornamental flowering plants. A circular hole was cut in a piece of cardboard and the root system or branches of diseased plants were pulled through the hole and projected into a jar of water, while the foliage and flowers were enclosed in a cage. Sometimes branches were cut from a large number of diseased plants, and then groups of branches from different plants, 6 or 8 to a cage, were tested for curly top; or at other times entire plants were transplanted with the root system from the field and each was tested singly. Twenty previously noninfective male beet leafhoppers were fed for a period of 2 days on the diseased plants and then transferred to 2 healthy beet seedlings in cages; two were used in case one seedling died owing to damping-off. Males were used rather than females so as to avoid egg deposition. A high rate of mortality of the inseets often occurred in the greenhouse because of unfavorable food plants. If symptoms of curly top failed to develop in from 1 to 2 weeks, the beets were examined daily in insect-proof chambers for a period of 3 months. If a beet developed curly-top symptoms, it was evident that the ornamental flowering plant had been naturally infected with the disease in the field. 
Yellows.-It was sometimes difficult to determine whether an ornamental flowering plant was naturally infected with curly top or yellows, and hence tests were made for both diseases when symptoms could not be reliably distinguished. The two species of leafhoppers were placed on the diseased plant at the same time. Previously noninfective Cicadula divisa were exposed to the diseased plants for a period of 3 days and were then transferred to healthy aster and celery plants and the beet leafhoppers were transferred to 2 healthy beet seedlings. If the aster and celery plants developed symptoms of yellows or if the beets developed curly top, it was evident that the ornamental flowering plant had been infected with one of the diseases under natural conditions. No ornamental flowering plant has been shown to be naturally infected with the two diseases simultaneously up to the present time.

\section{Curly-Top Symptoms}

Ornamental flowering plants sometimes showed reliable symptoms of curly top, and yet previously noninfective beet leafhoppers exposed to the naturally infected plants failed to transmit the virus to healthy sugar beets. A detailed description of the curly-top symptoms on the sugar beet has been given in a previous paper, ${ }^{(16)}$ and only the reliable and constant foliage symptoms will be briefly described in this paper. The earliest symptom plainly visible to the eye is a cleared or transparent network of minute veins generally occurring on the innermost or youngest leaves of the beet. Another reliable and constant symptom of curly top, developing usually after the veinlets have become transparent, is the presence on the lower surface of the leaves of numerous protuberances or small elevations on the veins resembling tiny warts. As the disease progresses, nipple-like papillae and knot-like swellings resembling galls develop here and there on the distorted veins. A clear viscid liquid which later turns black often exudes from the petioles, midrib, or veins.

\section{Chenopodiaceae, Goosefoot or Saltbush Family}

Common summer-cypress (Kochia scoparia var. trichophila) growing on the University campus at Davis was proved to be naturally infected with curly top. It was found that many of the plants were stunted and 40 per cent of the plants were dead owing to curly top.

The symptoms which developed on young plants experimentally infected with curly top were more pronounced than on naturally infected plants. The leaves at the apical end of the branches and secondary shoots were dwarfed and twisted (fig. $1 \mathrm{~A}$ ). The leaves were often twisted into a spiral (fig. $1 D$ ). The margin of the leaves and midrib was often sinuous 


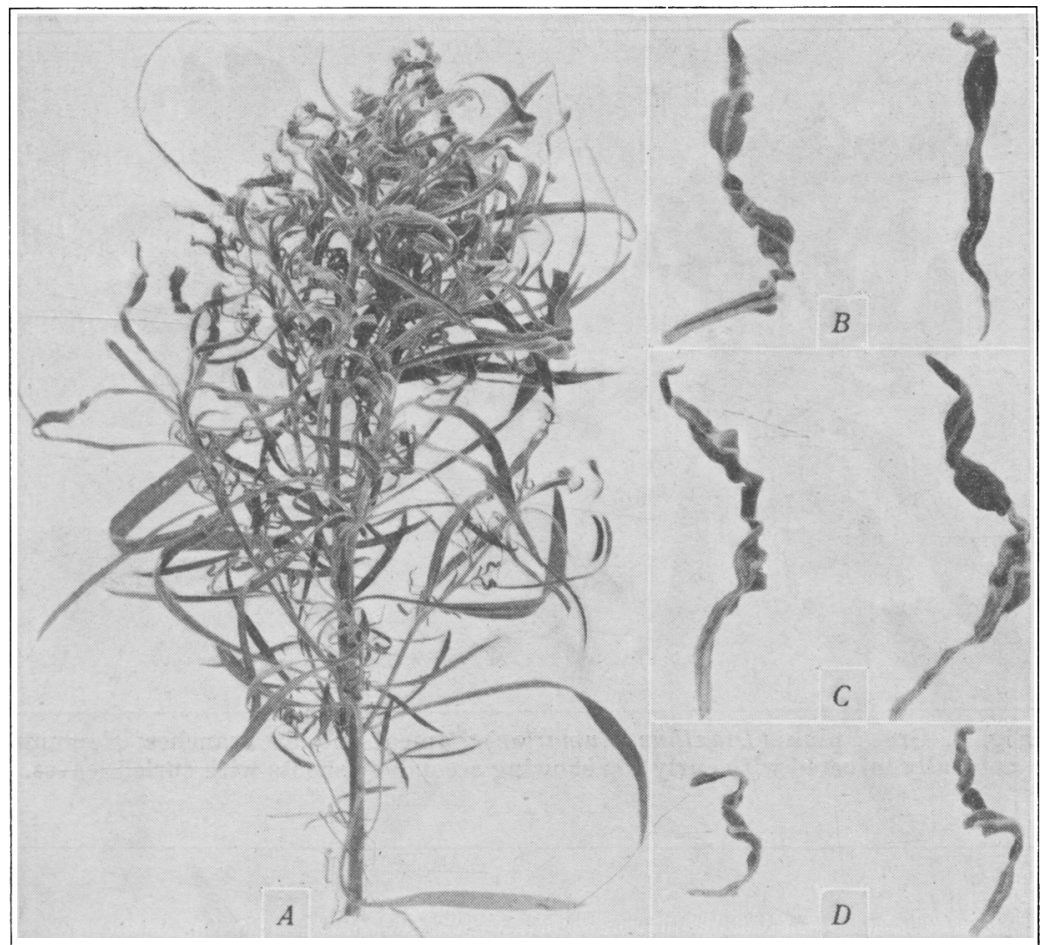

Fig. 1. Common summer-cypress (Kochia scoparia var. trichophila): $A$, Plant experimentally infected with curly top showing dwarfed and twisted leaves at the apical end of the branches and secondary shoots. $B, C$, Leaves with sinuous margins and midrib. $D$, Leaves showing spiral twist.

(fig. $1 B, C$ ), with knot-like swellings on the midrib. The leaves showed blister-like elevations on the lower surface and cleared or transparent veinlets.

\section{Amaranthaceae, Amaranth Family}

Cockscomb (Celosia argentea var. cristata) grown in the flower gardens of the Merced County Hospital was demonstrated to be naturally infected with curly top. Some of the plants were stunted, but no detailed study of other symptoms were made.

\section{Nyctaginaceae, Four-o'Clock Family}

Common four-o'clock (Mirabilis jalapa) growing on the Spreckels Ranch near King City in the Salinas Valley was proved to be naturally infected with curly top during the 1925 outbreak of the beet leafhopper. The leaves near the apices of the shoots showed a pronounced inward rolling toward the midrib and were thick, hard, and brittle. 


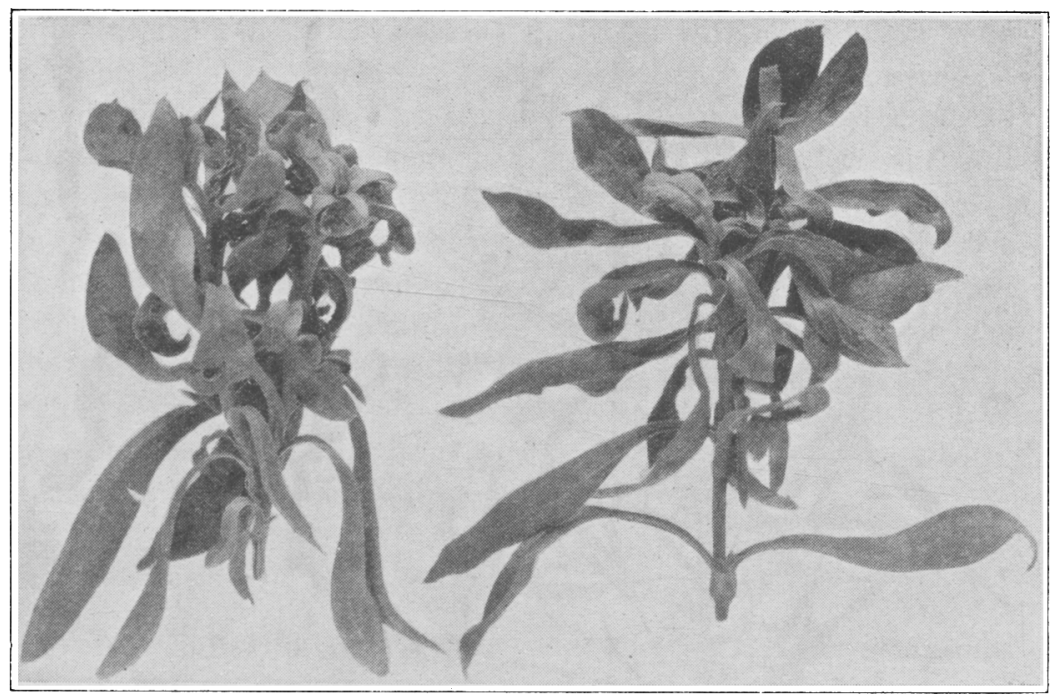

Fig. 2. Grass pink (Dianthus plumarius) : apical end of branches of plants naturally infected with curly top showing secondary shoots with curled leaves.

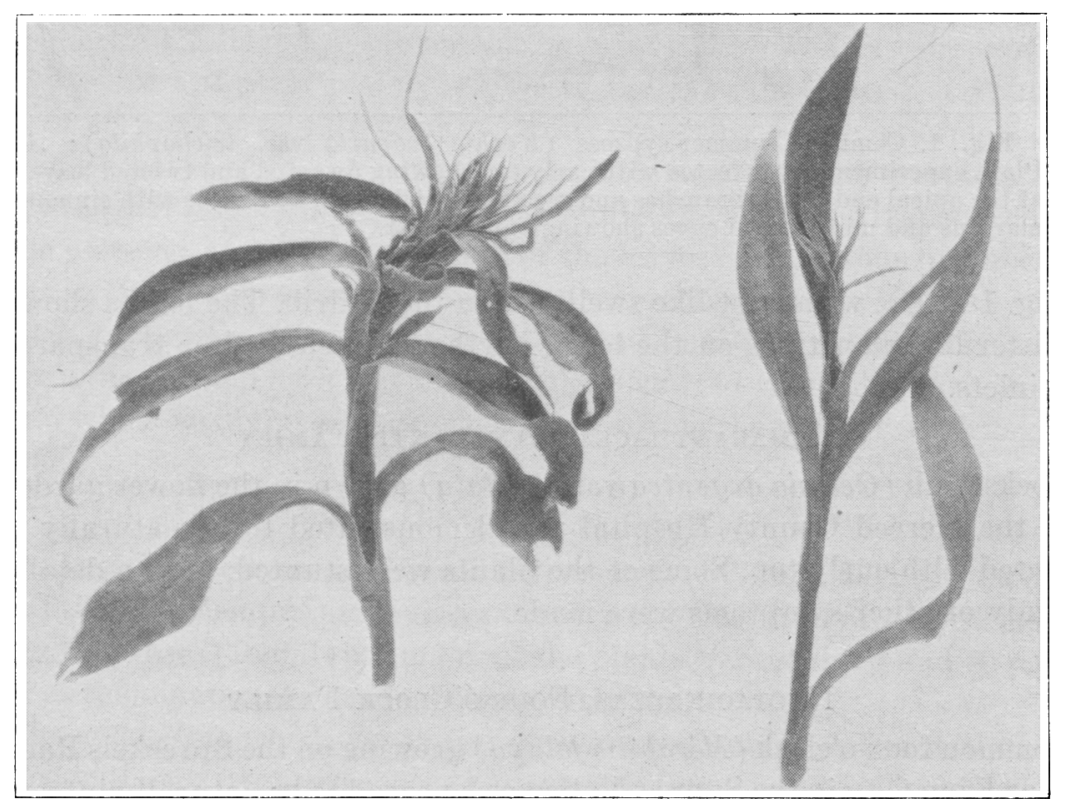

Fig. 3. Grass pink (Dianthus plumarius) : left, apical end of branch of plant naturally infected with eurly top showing proliferation of linear bracts around flower bud; right, branch from healthy plant showing flower bud surrounded by four linear bracts. (Keyes, San Joaquin Valley, November 9, 1932.) 


\section{Caryophyllaceae, Pink Family}

Grass pink (Dianthus plumarius) was demonstrated to be naturally infected with curly top in the San Joaquin Valley and showed pronounced symptoms of the disease. The internodes were shortened near the apices of the branches with secondary shoots (fig. 2) arising from the axils of the leaves. The larger leaves were curled (fig. 2 ) while the smaller leaves were dwarfed, curled, and twisted (fig. $4 A$ ) with cleared or transparent

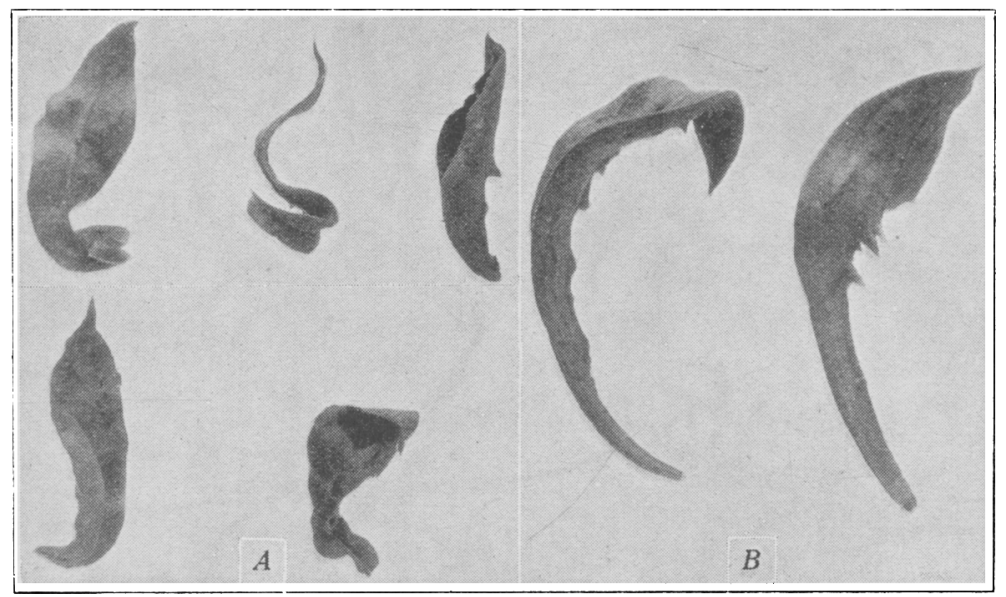

Fig. 4. Grass pink (Dianthus plumarius) : $A$, Leaves from secondary shoots of plant naturally infected with curly top showing dwarfed, twisted, and puckered condition. $B$, Leaves from secondary shoots showing spines on the midrib. (Keyes, San Joaquin Valley, November 9, 1932.)

veinlets. On the lower surface of the leaves, protuberances were present on the distorted veins, resembling thorns on the midrib (fig. $4 B$ ). The upper surface of the smaller leaves was often puckered (fig. $4 A$ ). Numerous linear bracts were often present around the flower buds (plate $1 A$, fig. 3), instead of the normal number, four. The flowers on infected plants were dwarfed and white in color (plate 1A).

Carnation (Dianthus caryophyllus) appeared to be naturally infected with curly top in the San Joaquin Valley, but noninfective beet leafhoppers failed to recover the virus. The older leaves were often bent down, rolled, or twisted (fig. 5A). The leaves of the secondary shoots were dwarfed and sometimes formed a dense cluster (fig. $5 C$ ). A diseased plant sometimes showed proliferation of leaves on dwarfed axillary shoots and normal leaves on healthy shoots (plate $2 A$ ), indicating apparently a recovery from curly top. The flower buds at the apices of the branches were often dwarfed with the teeth of the calyx bent inward 


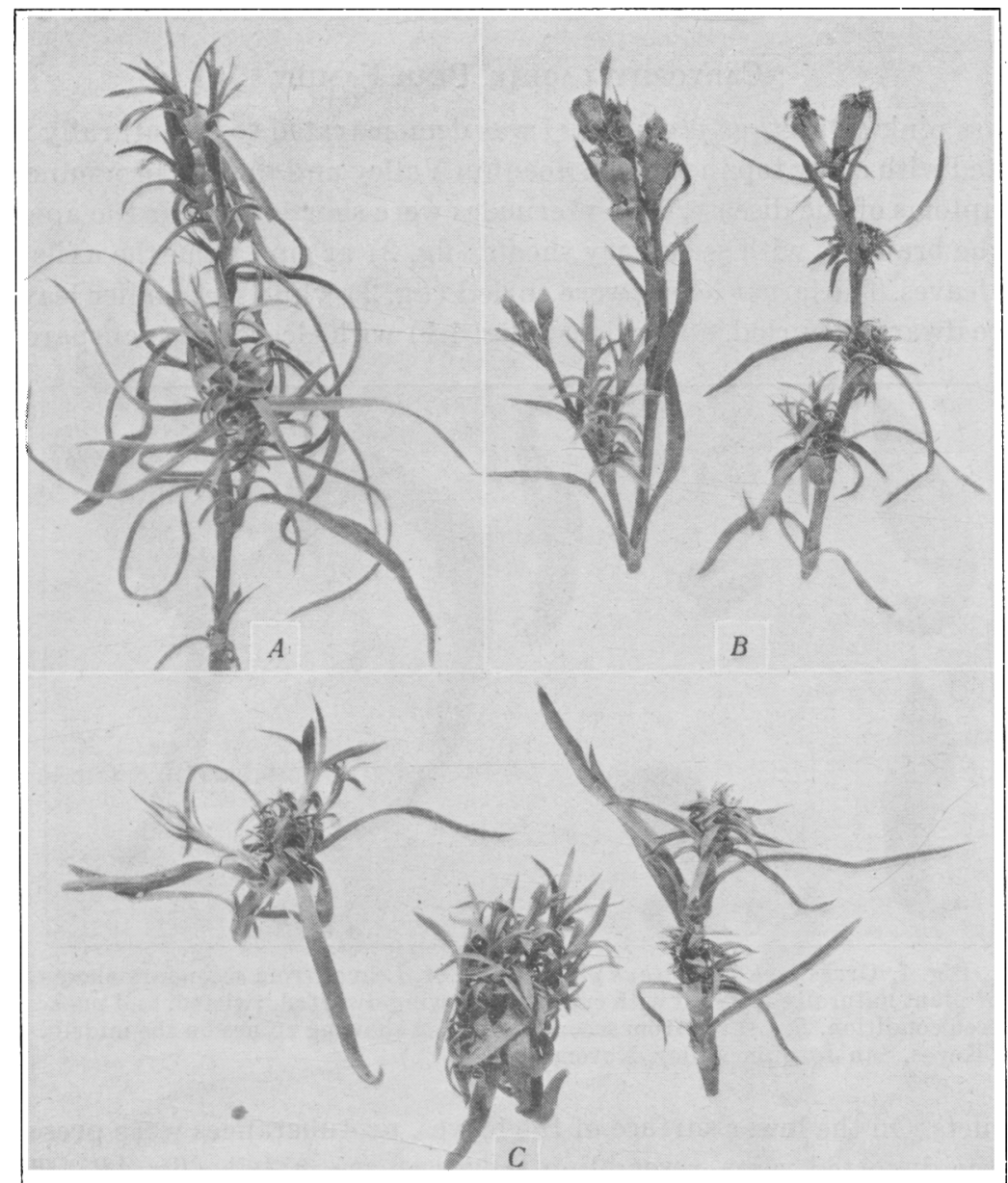

Fig. 5. Carnation (Dianthus caryophyllus) : A, Apical end of stem showing secondary shoots. $B$, Stems showing dried flower buds at the tip and rosettes of small leaves surrounding the flower buds at the end of the secondary shoots. $C$, Secondary shoots showing a dense cluster of dwarfed leaves. (Keyes, San Joaquin Valley, November 9, 1932.)

forming a bell-shaped bud (plate $1 B$ ) containing the withered flower parts. The flower buds at the tip of the secondary shoots were dwarfed with rosettes of small linear leaves (fig. $5 B$.). The flowers sometimes were dwarfed or the petals were dry (plate $1 B$ ).

\section{Ranunculaceae, Crowfoot Family}

Turban and Persian buttercups (Ranunculus asiaticus) demonstrated to be naturally infected with aster yellows were collected by L. W. Massey in an acre field owned by Luther Gage, Carlsbad, California. This 


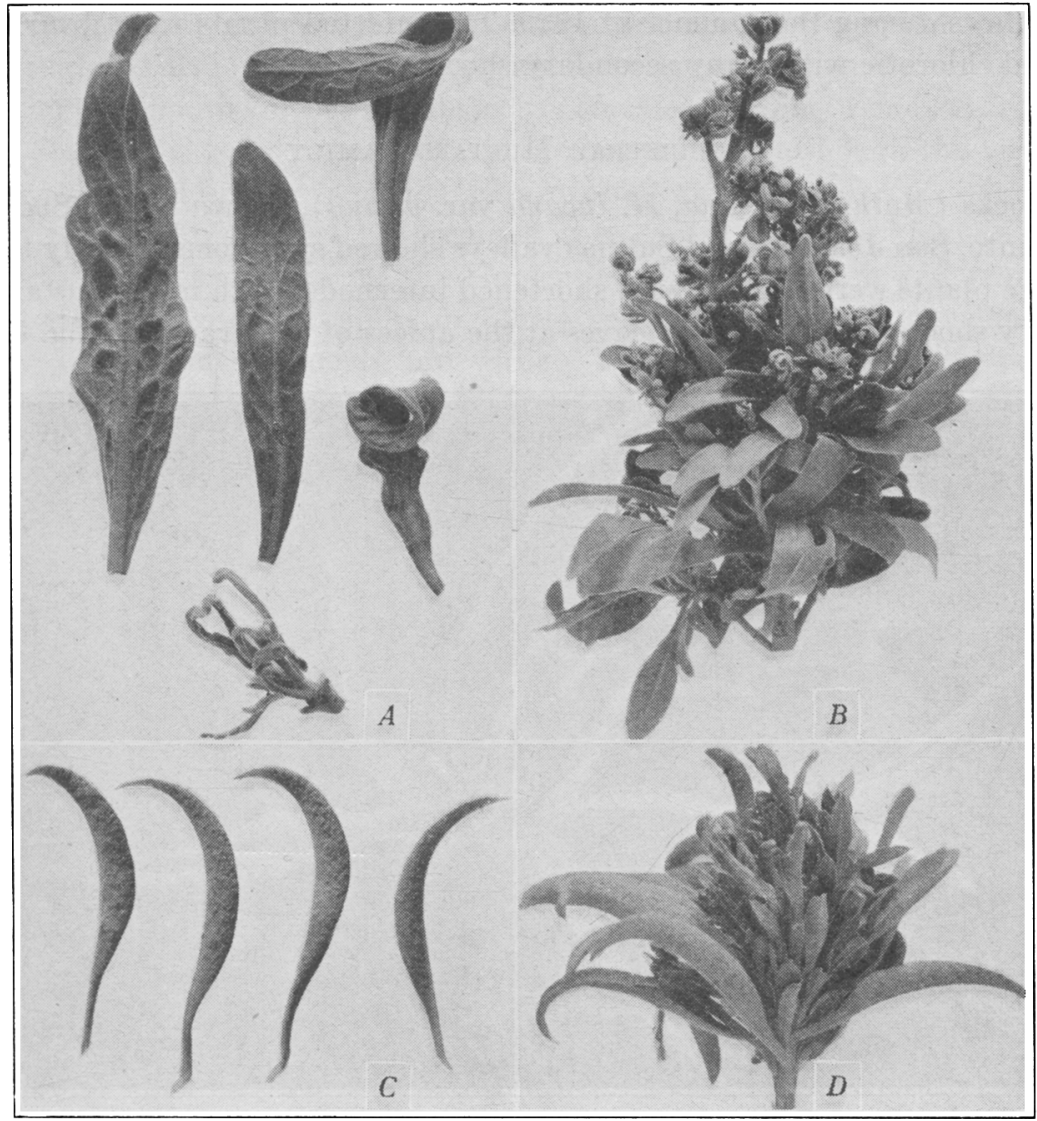

Fig. 6. Annual stock (Mathiola incana var. annua): A, Left, two leaves showing distorted veins with protuberances; right, two leaves showing curled and twisted blades; lower, secondary shoot with linear leaves (Davis, Sacramento Valley, November 1, 1932). B, Apical end of branch from plant naturally infected with curly top showing cluster of dwarfed flower stalks on secondary shoots (Chowchilla, San Joaquin Valley, November 9, 1932). C, Inward-curled leaves showing protuberances resembling tiny warts. $D$, Side view of terminal end of branch showing cluster of secondary shoots.

is the first record of the occurrence of aster yellows in San Diego County. The percentage of diseased plants was estimated at between 1 and 2 per cent. The diseased plants were yellow with numerous secondary shoots. The flowers were green and often dwarfed with petals reduced in size (plate $2 B$ ).

\section{Papaveraceae, Poppy Family}

California poppy (Eschscholtzia californica) growing on a ranch of a seed company near Salinas and in a flower bed near the Spreckels Agriculture Experiment Station was proved to be naturally infected with 
yellows during the summer of 1929 . The infected plants were dwarfed and chlorotic with many secondary shoots.

\section{Cruciferae, Mustard Family}

Stocks (Mathiola incana, M. incana var. annua), grown in the Sacramento, San Joaquin, and Salinas valleys showed symptoms of curly top. The plants were stunted with shortened internodes with numerous axillary shoots bearing linear leaves at the apices of the branches (fig. $6 \mathrm{~A}$,

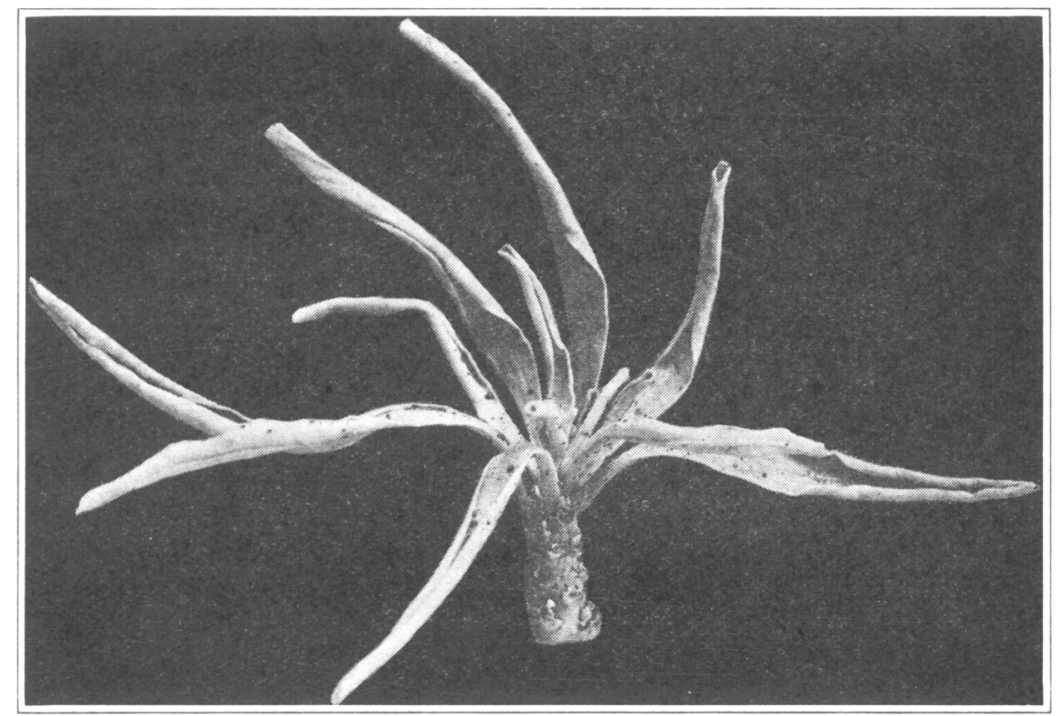

Fig. 7. Annual stock (Mathiola incana var. annua): apical end of branch from a plant naturally infected with curly top showing white leaves with droplets of liquid which exuded from the blades, petioles, and stem. (Lodi, San Joaquin Valley, August 11, 1932.)

$D$ ). The leaves of the axillary shoots were sometimes twisted (fig. $6 \mathrm{~A}$ ) and often the margin of the leaves were curled or rolled inward. The veins on the lower surface of the leaves were distorted (fig. $6 \mathrm{~A}$ ) with protuberances resembling tiny warts (fig. $6 C$ ). The apices of the leaves of some plants were purple or yellow. The lower leaves of plants in an advanced stage of the disease were dry, and the leaves near the terminal end of the shoots were white. Brown droplets of liquid exuded from the blades, petioles, and stem (fig. 7), and were also present in experimentally infected stocks (M. incana var. annua). The flower stalks from numerous axillary shoots formed a dense cluster (fig. 6B) and the flowers were often malformed with dried petals.

Enormous populations, of beet leafhoppers were found on stocks in 
the Sacramento and San Joaquin valleys, and many of the plants were stunted and often dead. Previously noninfective leafhoppers after feeding on the biennial or perennial stocks (Mathiola incana) removed from the field failed to transmit curly top to sugar beets, although the virus was recovered from experimentally infected annual stock (M. incana var. annua). In one test 140 nymphs were captured on the biennial or perennial stocks grown on the University Farm at Davis and transferred in lots of 20 nymphs to 7 beet seedlings. One beet developed typical symptoms of curly top while 6 remained healthy. There is a possibility that some of the nymphs might have acquired the virus from weeds infected with curly top. In a previous paper ${ }^{(15)}$ it was reported that different varieties of crucifers grown from seeds were inoculated with curly top by infective beet leafhoppers, but the transmission of the disease by previously noninfective leafhoppers after feeding on inoculated plants to sugar beets was not often accomplished.

\section{Geraniaceae, Geranium Family}

Fish geranium (Pelargonium hortorum) showed symptoms of curly top during the autumn in many localities in the San Joaquin Valley. Small elevations resembling tiny warts (plate $3 E$ ) were present on the lower surface of the older leaves but were absent on the younger leaves. In a cemetery near Los Banos where the geraniums were watered regularly, an inward rolling of the margin or cupping of some of the leaves occurred (plate $3 B$ ), but leaf rolling was not observed in other localities. The leaves sometimes were chlorotic (plate $3 E$ ), and entire plants were yellow and appeared to be in an advanced stage of the disease.

Fish geraniums which showed symptoms of curly top during the autumn were again examined during the following spring. The leaves on young shoots which grew from the roots showed reliable symptoms of the disease. The leaves were cupped inward, with sinuous veins (plate $3 D$ ), cleared veinlets (plate $3 C$ ), and protuberances on the lower surface. The older leaves were chlorotic between the veins, while the area in the vicinity of the veins was green. The apical leaves on the old branches showed protuberances on the lower surface, with dwarfed chlorotic leaves which developed from the nodes (plate $3 A$ ). The older branches were yellow instead of green. During the spring the virus was transferred by previously noninfective beet leafhoppers from 6 of 7 naturally infected plants to sugar beets, but during the autumn the virus was recovered from only 2 of the same 7 plants.

Cuttings from naturally infected geraniums collected during the autumn and kept in the greenhouse during the winter and spring failed to show symptoms of the disease on the younger leaves. These cuttings 


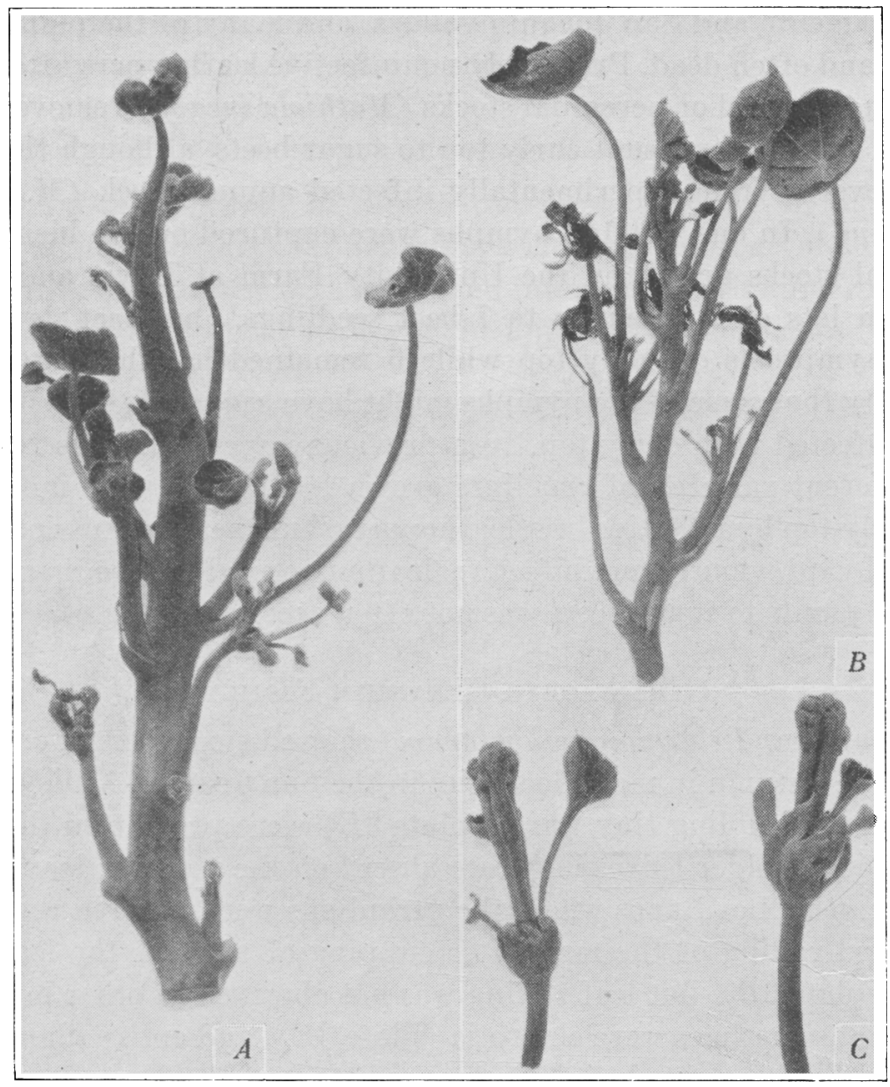

Fig. 8. Dwarfed type of common nasturtium (Tropaeolum majus ): $A$, Apical end of stems and secondary shoots showing dwarfed blades. $B$, Apical end of branch showing cupped leaves, secondary shoots with small blades and dried flowers. $C$, Flowers with enlarged pistils and cupped leaves. (Davis, Sacramento Valley, November 1, 1932.)

were exposed to infective beet leafhoppers and typical symptoms of curly top developed. The virus was recovered from the infected cuttings by previously noninfective leafhoppers and transferred to sugar beets.

Single giant-flowering hybrid geranium grown from seeds experimentally infected with curly top showed an inward rolling of the basal portion of the leaves or an inward or outward cupping of the leaves. The youngest leaves showed cleared or transparent veinlets. Previously noninfective beet leafhoppers transmitted the virus from the infected geraniums to sugar beets. A variety of geranium known as Mrs. Pollock was also experimentally infected with curly top. 


\section{Tropaeolaceae, Tropaeolum Family}

An unknown variety of nasturtium (Tropaeolum majus), growing in the vicinity of the ranch houses of the California Packing Corporation near Tracy, was stunted (plate $4 A$ ) and most of the plants apparently had been destroyed by curly top. The virus was recovered from 1 of 3

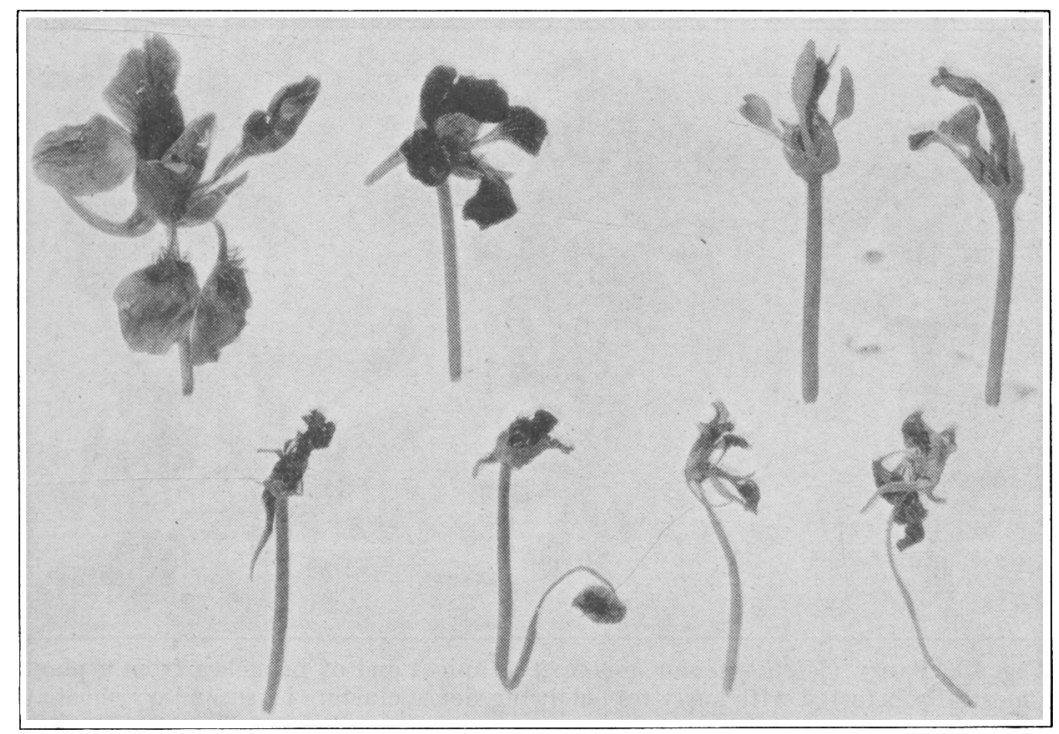

Fig. 9. Dwarfed type of common nasturtium (Tropaeolum majus) : upper row left, normal flower from a healthy plant; second, dwarfed flower from a plant naturally infected with curly top; third and fourth, malformed flowers; lower row, flowers with dried sepals and petals. (Davis, Sacramento Valley, November 1, 1932.)

plants by previously noninfective beet leafhoppers and transferred to sugar beets.

It was found that about one-third of the common dwarf garden nasturtium (Tropaeolum majus) grown on the University Farm at Davis showed symptoms of curly top. Previously noninfective beet leafhoppers exposed to cuttings from 43 stunted plants failed to transmit curly top to sugar beets.

Nasturtiums apparently infected with curly top were also found in the interior districts of the Salinas Valley.

The outer or older leaves of naturally infected plants were usually yellow. Numerous secondary shoots (plate $4 A$ ) were present on naturally infected plants with dwarfed, cupped (fig. 8A, B) and sometimes puckered leaves with distorted veins. The dwarfed leaves were some- 
times dry; occasionally the petiole below the blade was withered, while the remainder of the petiole was green. The leaves near the apices of the secondary shoots were dwarfed; they had small blades (fig. $8 A$ ) with the margins rolled inward.

The sepals and petals of immature flowers were withered or dry (fig. 9 ). The flower buds usually were dwarfed, chlorotic, and failed to expand. The pistil sometimes was greatly enlarged (fig. $8 C$ ).

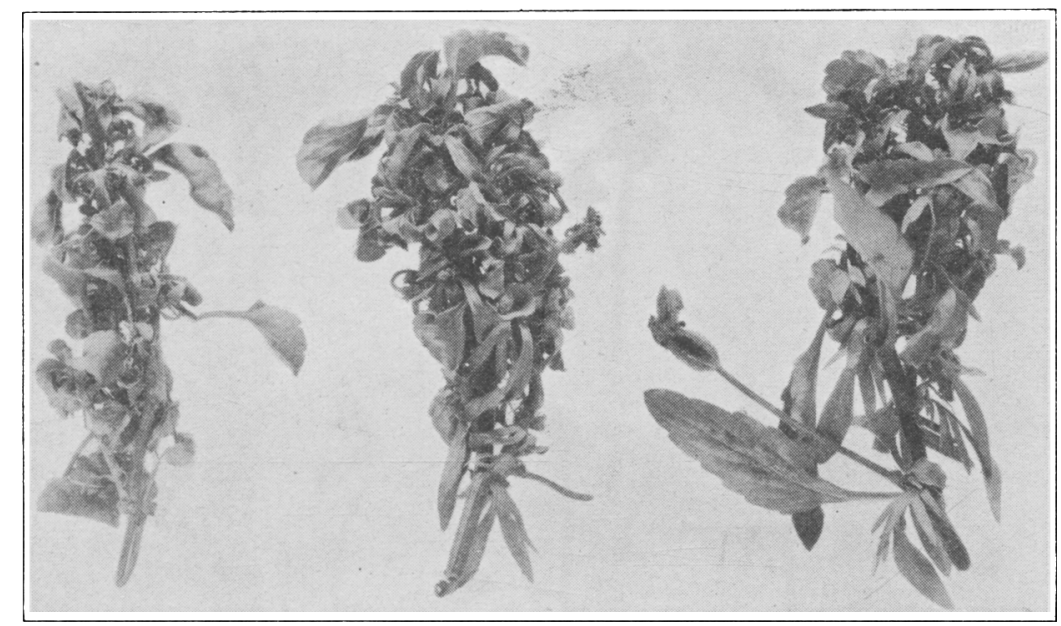

Fig. 10. Pansy (Viola tricolor hortensis) : apical end of branches from a plant naturally infected with curly top, showing dense clusters of secondary shoots.

Dwarfed mixed varieties of nasturtium were resistant to experimental infection with curly top. The virus was transferred to sugar beets by previously noninfective beet leafhoppers from only 2 of the 20 plants inoculated.

Carsner ${ }^{(2)}$ reported that Tropaeolum majus was nonsusceptible to curly top.

\section{Violaceae, Violet Family}

Giant Trimardeau pansy (Viola tricolor var. hortensis) and Apricot Queen viola (Viola cornuta) were demonstrated to be naturally infected with curly top in the Salinas Valley.

The most conspicuous symptom of the disease was the dense cluster of chlorotic secondary shoots arising from the axil of the leaves near the tips of the branches (fig. 10) of the stunted plants. The margin of the leaves were rolled inward or cupped along the midrib, or the tips of the leaves were rolled toward the petioles. The youngest leaves showed cleared or transparent veinlets. The veins were wavy and bore small protuberances or papillae. 
Dwarfed linear leaves surrounded the flower buds near the tip of the secondary shoots. The flower buds were often sessile, sometimes with a short peduncle. The flowers were dwarfed and frequently dry (fig. 11).

\section{Onagraceae, Evening-Primrose Family}

The Sybil Sherwood godetia (Godetia grandiflora) was found to be naturally infected with yellows in the Salinas Valley. Infected plants were chlorotic, with dwarfed curled leaves near the tips of the branches.

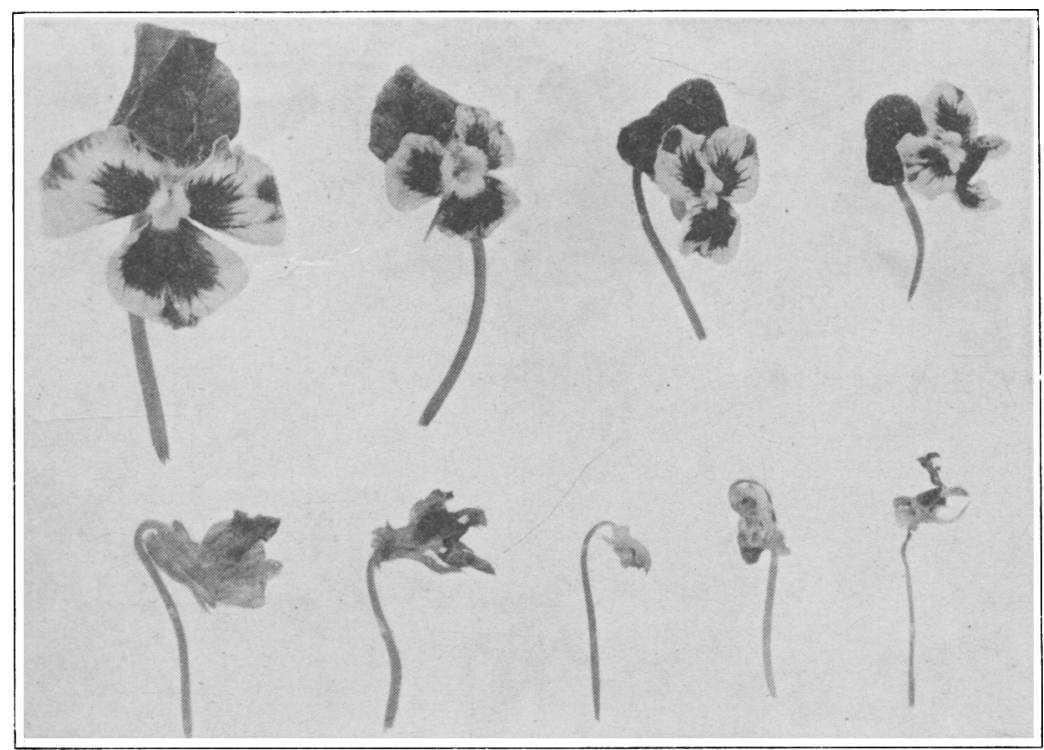

Fig. 11. Pansy (Viola tricolor hortensis) : upper row left, normal flower from healthy plant, and three dwarfed flowers from a diseased plant; lower row, dwarfed and dried flowers. (Greenfield, Salinas Valley, November 3, 1932.)

\section{Solanaceae, Nightshade Family}

Common petunia (Petunia hybrida) was proved to be naturally infected with curly top in the Sacramento, San Joaquin, and Salinas valleys. The Rosy Morn variety (Petunia hybrida) grown in the flower beds adjacent to the University headhouses and greenhouses at Berkeley and the Double Ruffled variety (Petunia hybrida) grown along the highway near Davis were demonstrated to be naturally infected with curly top. Common petunias grown near Salinas, on the University Farm at Davis, and plants sent from Edgewood, Siskiyou County, were proved to be naturally infected with the disease.

Rosy Morn petunia transplanted in beds at Berkeley and then infected with curly top were stunted and developed numerous secondary shoots 


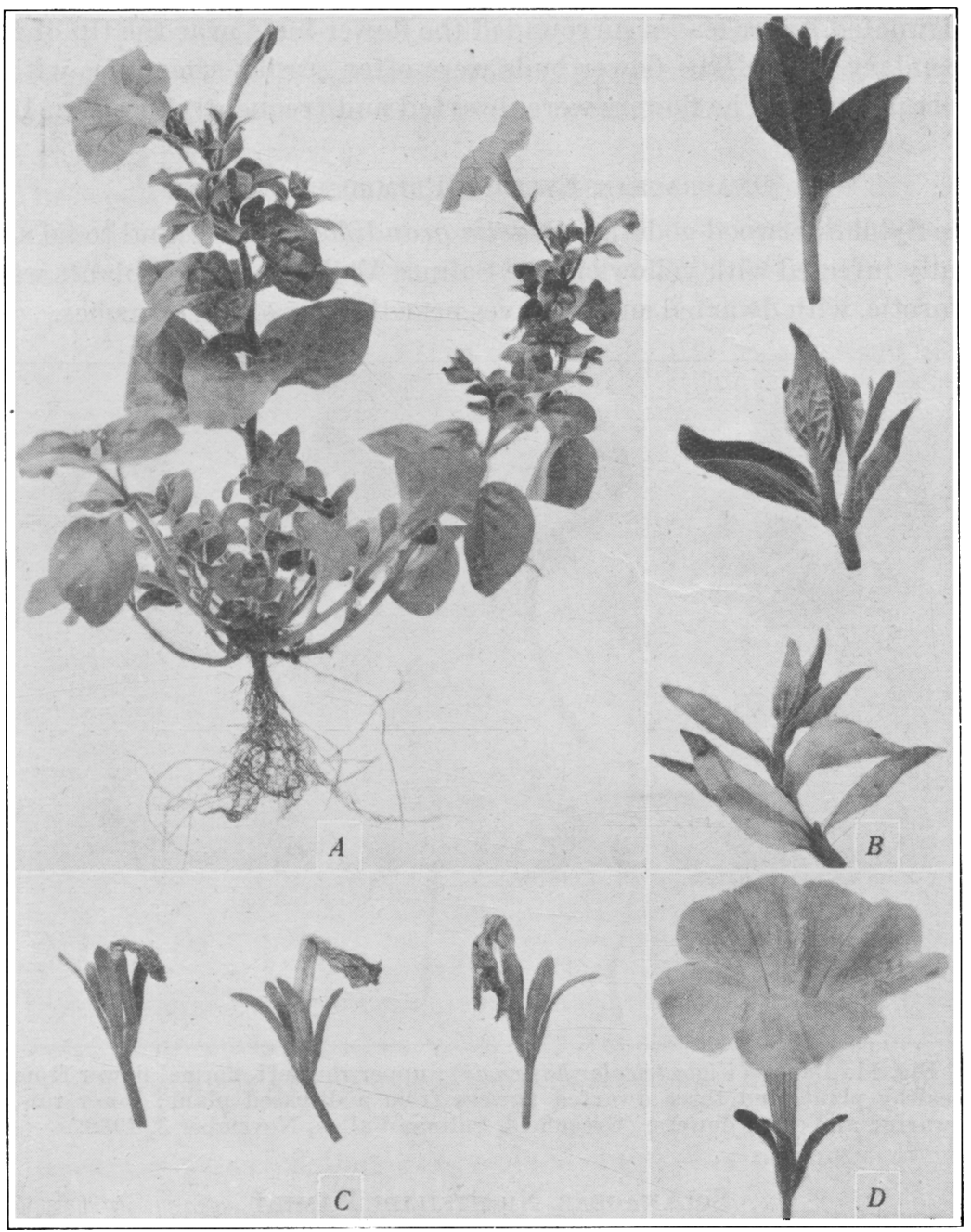

Fig. 12. Rosy Morn petunia (Petunia hybrida): A, Plant naturally infected with curly top showing abnormal development of secondary shoots. $B$, Upper, apical end of shoot from healthy check or control plant; center, apical end of shoot from plant naturally infected with curly top showing distorted veins with protuberances; apical end of shoot from plant in an advanced stage of the disease showing chlorotic leaves. $C$, Flowers from a plant naturally infected with curly top showing dried corollas. $D$, Flower from healthy check or control plant. (Berkeley, June 17, 1931.)

(fig. 12A) with dwarfed cupped leaves. Protuberances on the veins on the lower surface of the leaves of the secondary shoots and apical ends of the branches (fig. 12B) gave the veins a roughened appearance. The corolla of the flowers often failed to expand and became dry (fig. 12C). In the later stage of the disease the entire plant turned yellow and died. 
Kunkel $^{(8)}$ has experimentally infected Petunia hybrida with aster yellows: Previously noninfective Cicadula divisa failed to transmit yellows to asters and celery from diseased petunias removed from the field.

\section{Dipsaceae, Teasel Family}

Sweet scabiosa (Scabiosa atropurpurea) growing in a cemetery at King City in the Salinas Valley was proved to be naturally infected with curly top. The plants were stunted and chlorotic, but no other symptoms of the disease were noted.

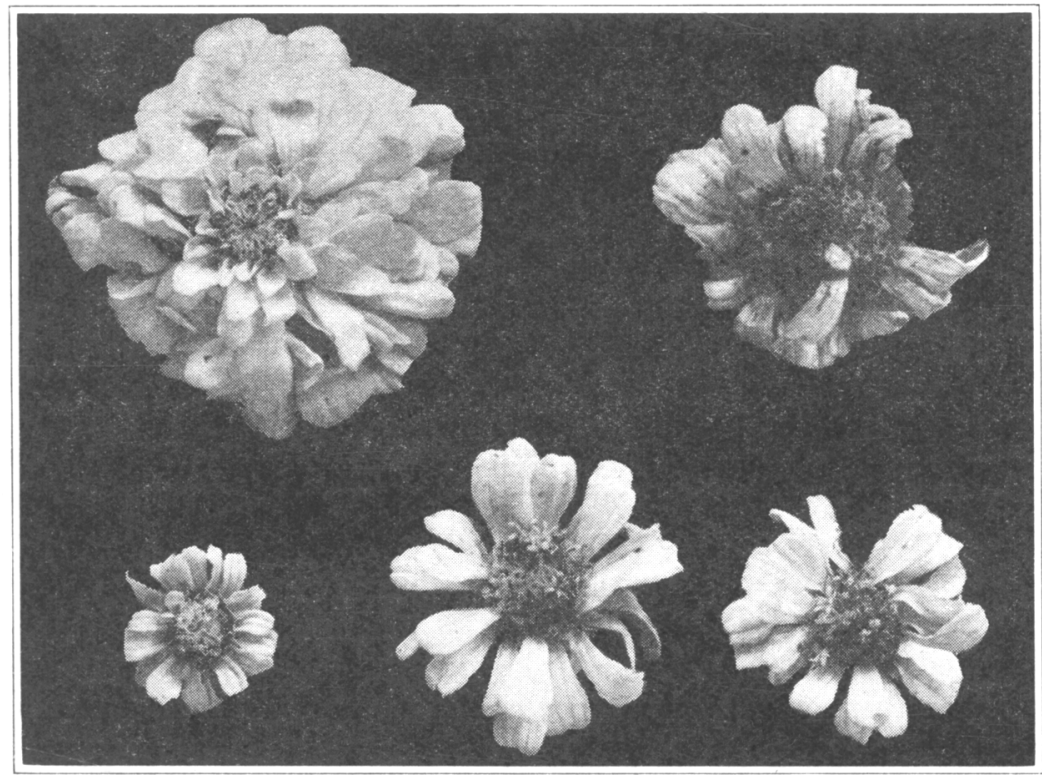

Fig. 13. Common zinnia (Zinnia elegans): upper row left, normal flower from a healthy plant; remainder, dwarfed flowers with petals reduced in number, from a plant naturally infected with curly top. (Keyes, San Joaquin Valley, November 9, 1932.)

\section{Compositae, Composite Family}

The Single Eldorado corn-marigold chrysanthemum (Chrysanthemum segetum) was demonstrated to be naturally infected with yellows in the Salinas Valley. The secondary shoots were chlorotic, the flower buds dwarfed, and petals reduced in number on the flowers.

Common zinnia (Zinnia elegans) grown near San Juan and Salinas was proved to be naturally infected with curly top. Diseased zinnias were more abundant when grown adjacent to garden, table, or red beets than when among ornamental flowering plants. The internodes near the apices of the branches were shortened, with chlorotic secondary shoots 
(plate $2 C$ ) arising from the axils of the leaves. The flowers were dwarfed with the petals reduced in number (fig. 13).

In the greenhouse, Zinnia elegans and Mexican Double orange zinnia (Zinnia haageana) experimentally infected with curly top showed transparent or cleared veinlets on the youngest leaves (plate $2 D$ ), but this symptom could not be detected in the field.

Natural infection of zinnia with yellows disease was reported in a previous paper. ${ }^{(14)}$ Three varieties of zinnias, commonly known as Double Giant Pink, Dahlia Flowered mixed, and Lilliput Scarlet Gem (Zinnia elegans), grown near Salinas, were proved to be naturally infected with aster yellows. The virus was transferred by previously noninfective Cicadula divisa from the three varieties of zinnias to healthy celery. Naturally infected zinnias were often stunted and showed chlorotic secondary shoots. The symptoms of zinnia yellows, however, could not be distinguished from zinnia curly top on old plants; no study has been made in the field of the symptoms of the two diseases on young plants.

Common cosmos (Cosmos bipinnatus) was found to be naturally infected with curly top in the Salinas and San Joaquin valleys. The internodes were shortened toward the tips of the stems, and the apices of the branches and secondary shoots were yellow. The leaflets were often curled and twisted (fig. 14) and the petioles were bent downward; sometimes two adjacent petioles were bent parallel to the stem (fig. 14). The flower buds on the secondary shoots were dwarfed and surrounded by a cluster of small chlorotic leaves.

Crested cosmos (Cosmos hybrida) experimentally infected with curly top showed pronounced symptoms of the disease. The infected plants showed shortened internodes, chlorotic secondary shoots and apices of the branches, and curled and twisted leaves (fig. 15).

Calliopsis (Coreopsis tinctoria) growing in a cemetery near King City in the Salinas Valley was demonstrated to be naturally infected with curly top. The plants were stunted but showed no foliage symptoms of the disease.

Dwarfed French marigold (Tagetes patula) was proved to be infected with yellows on the University campus at Berkeley. The infected plants were stunted and chlorotic. A dense cluster of secondary shoots with dwarfed leaves and numerous flower buds developed at the tip of the branches (fig. 16A). The flower buds often failed to expand (fig. 16B). In the later stages of the disease, the plants died.

Aztec (African) marigold (Tagetes erecta) was demonstrated to be naturally infected with yellows in Berkeley. The infected plants were dwarfed and yellow and failed to blossom. ${ }^{(14)}$ 


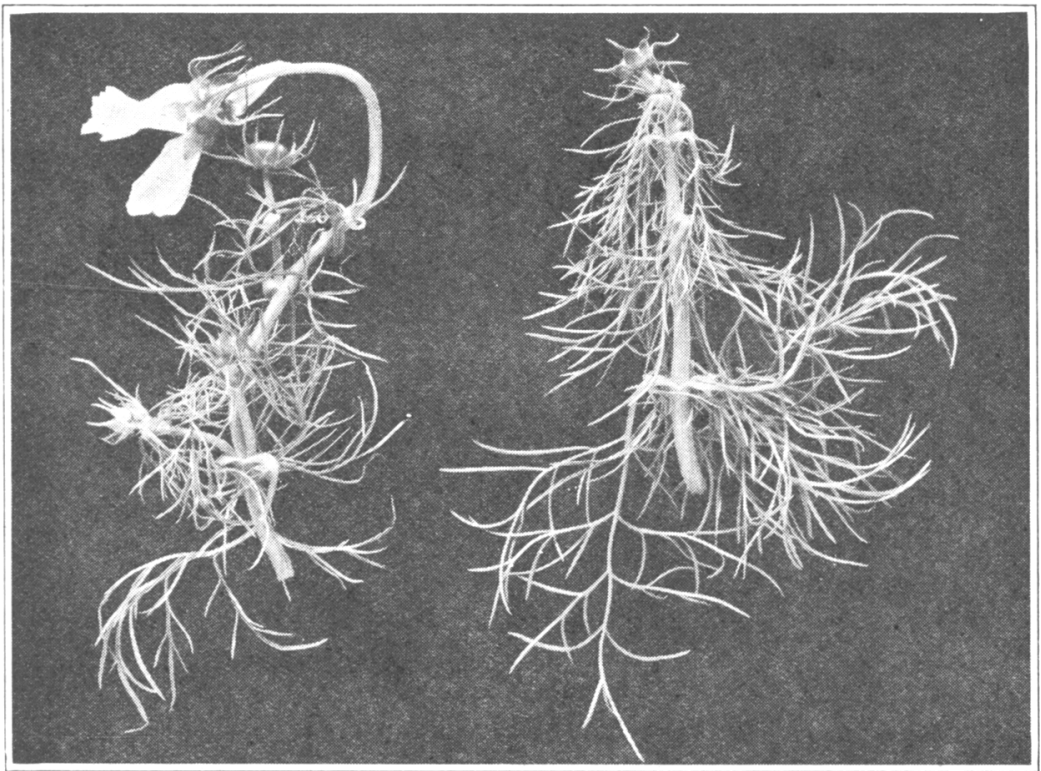

Fig. 14. Common cosmos (Cosmos bipinnatus) : apical ends of branches from a plant naturally infected with curly top showing bent petioles with curled and twisted leaves. (Salinas Valley, August 18, 1932.)

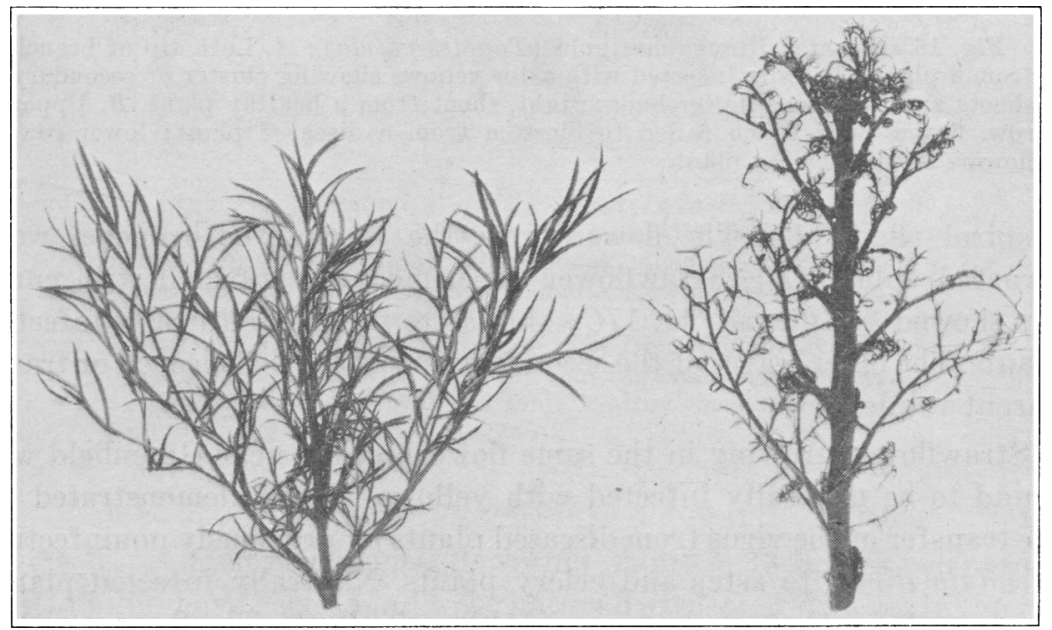

Fig. 15. Crested cosmos (Cosmos hybrida): Left, apical end of shoot from healthy plant; right, apical shoot from a plant experimentally infected with curly top showing secondary shoots and curled and twisted leaves. 
Strawflower (Helichrysum bracteatum) growing in a flower garden near Greenfield in the Salinas Valley, was demonstrated to be naturally infected with curly top. Numerous secondary shoots were present toward the tips of the branches (fig. 17A). The older leaves of the secondary shoots were curled outward with small protuberances on the distorted veins, while the younger leaves were linear and sometimes twisted into

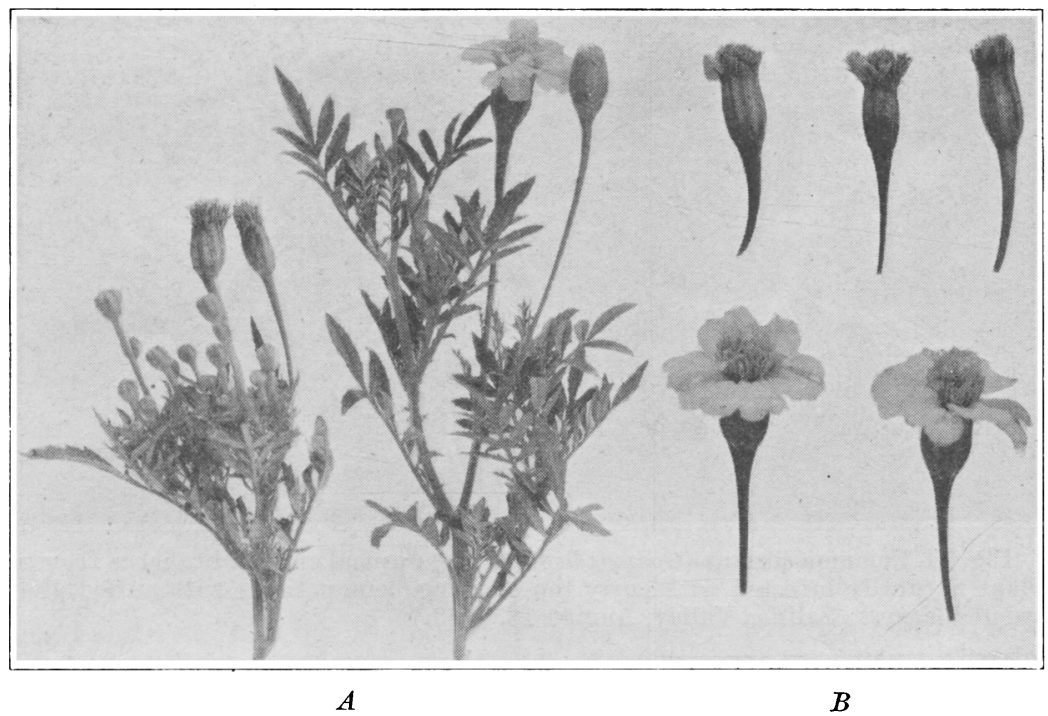

Fig. 16. Dwarfed French marigold (Tagetes patula) : A, Left, tip of branch from a plant naturally infected with aster yellows showing cluster of secondary shoots and numerous flower buds; right, shoot from a healthy plant. $B$, Upper row, flower buds which failed to blossom from a diseased plant; lower row, flowers from a healthy plant.

a spiral (fig. $17 B$ ). The flowers near the tips of the branches were dwarfed (plate $4 B$ ). Strawflower experimentally infected with curly top showed symptoms (fig. 17C) similar to those of naturally infected plants. The older leaves of the secondary shoots showed cleared or transparent veinlets.

Strawflower growing in the same flower garden near Greenfield was found to be naturally infected with yellows, as was demonstrated by the transfer of the virus from diseased plants by previously noninfective Cicadula divisa to aster and celery plants. Naturally infected plants were stunted and showed numerous chlorotic shoots. The flowers on the secondary shoots were green. Strawflower yellows could be distinguished from strawflower curly top by the absence of protuberances on the lower surface of the leaves. 


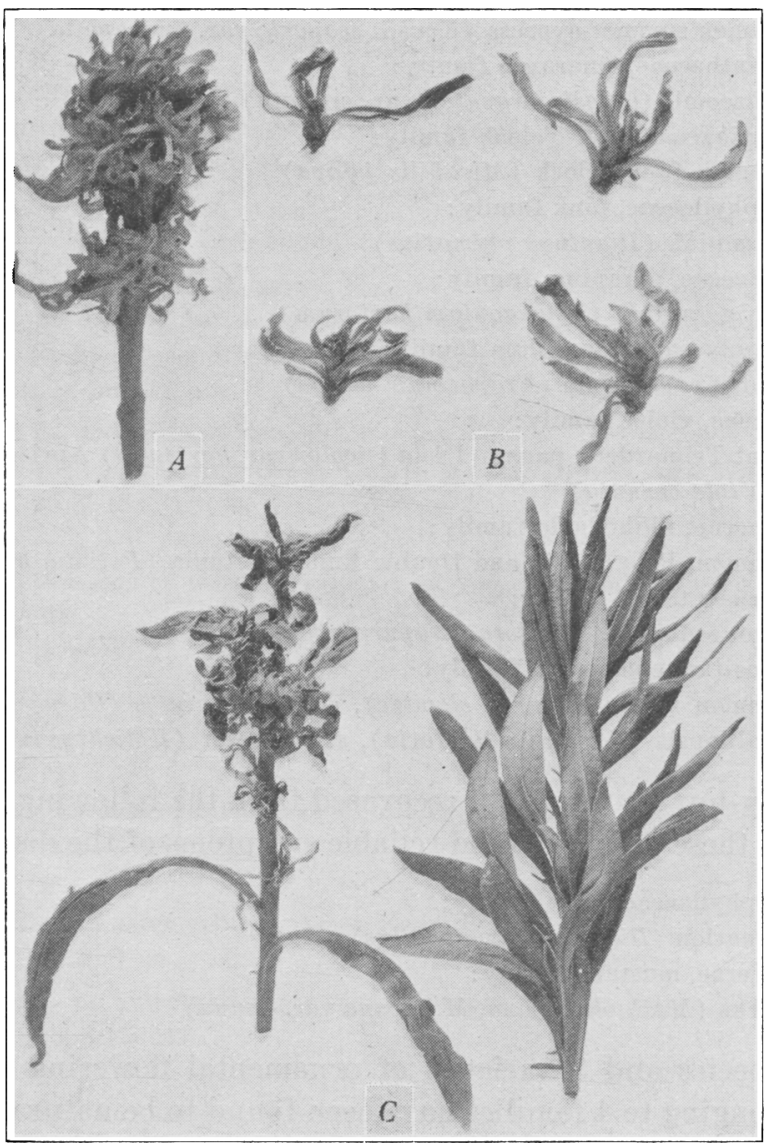

Fig. 17. Strawflower (Helichrysum bracteatum): $A$, Apical end of branch from a plant naturally infected with curly top showing numerous secondary shoots bearing filamentous leaves. $B$, Secondary shoots showing twisted and spiral leaves (Greenfield, Salinas Valley, November 3, 1932). $C$, Left, apical end of branch from a plant experimentally infected with curly top showing secondary shoots; right, apical end of branch from a healthy check or control plant.

\section{Summary}

Fourteen species of ornamental flowering plants in 13 genera belonging to 10 families have been found to be naturally infected with curly top in California. Previously noninfective beet leafhoppers transferred the curly-top virus from the following 14 species of naturally infected plants to sugar beets. 
Chenopodiaceae, goosefoot or saltbush family:

Common summer-cypress (Kochia scoparia var. trichophila)

Amaranthaceae, amaranth family :

Cockscomb (Celosia argentea var. cristata)

Nyctaginaceae, four-o'clock family:

Common four-o'clock (Mirabilis jalapa)

Caryophyllaceae, pink family :

Grass pink (Dianthus plumarius)

Geraniaceae, geranium family:

Fish geranium (Pelargonium hortorum)

Tropaeolaceae, tropaeolum family:

Garden nasturtium (Tropaeolum majus)

Violaceae, violet family:

Giant Trimardeau pansy (Viola tricolor var. hortensis) Apricot Queen viola (Viola cornuta)

Solanaceae, nightshade family:

Common, Rosy Morn, and Double Ruffled petunia (Petunia hybrida)

Dipsaceae, teasel family:

Sweet scabiosa (Scabiosa atropurpured)

Compositae, composite family:

Common zinnia (Zinnia elegans), common cosmos (Cosmos bipinnatus), calliopsis (Coreopsis tinctoria), strawflower (Helichrysum bracteatum)

The curly-top virus was not recovered from the following 2 species of plants, but these plants showed reliable symptoms of the disease.

Caryophyllaceae, pink family:

Carnation (Dianthus caryophyllus)

Cruciferae, mustard family:

Stocks (Mathiola incana, M. incana var. annua)

Eight species and 3 varieties of ornamental flowering plants in 7 genera belonging to 4 families have been found to be naturally infected with aster yellows in California. Previously noninfective Cicadula divisa transferred the yellows virus from the following species and varieties of naturally infected plants to asters or celery :

Ranunculaceae, crowfoot family:

Turban and Persian buttercups (Ranunculus asiaticus)

Papaveraceae, poppy family :

California poppy (Eschscholtzia californica)

Onagraceae, evening-primrose family:

The Sybil Sherwood godetia (Godetia grandiflora)

Compositae, composite family:

The Single Eldorado corn-marigold chrysanthemum (Chrysanthemum segetum); common zinnia (Zinnia elegans): Double Giant Pink, Dahlia Flowered mixed, and Lilliput Searlet Gem; Dwarfed French marigold (Tagetes patula); Aztec (African) marigold (Tagetes erecta); and strawflower (Helichrysum bracteatum) 


\section{Literature Cited}

1 BALD, J. G., AND G. SAMUEL.

1931. Investigations on "spotted wilt" of tomatoes. Aust. Council for Sci. and Indus. Research. Bul. 54:1-24.

2 CARSNer, E.

1919. Susceptibility of various plants to curly top. Phytopathology 9:413-421.

3 Freitag, J. H., and H. H. P. Severin.

1933. List of ornamental flowering plants experimentally infected with curly top. Plant Disease Reporter 17:2-5. [Issued by the U. S. Dept. Agr. Bur. Plant Indus.]

4 Fromme, F. D., and S. A. Wingard.

1922. Blackfire or angular-leafspot of tobacco. Virginia Agr. Exp. Sta. Tech. Bul. 25:1-43.

5 Henderson, G. R.

1931. Transmission of tobaceo ringspot by seed of petunia. Phytopathology 21: 225-229.

6 Henderson, G. R.

1931. Further studies on tobaceo ringspot in Virginia. Jour. Agr. Research 43: 191-207.

7 Johnson, E. M.

1930. Virus diseases of tobacco in Kentucky. Kentucky Agr. Exp. Sta. Bul. 306: $287-415$.

8 KUNKEL, L. O.

1926. Studies on aster yellows. Amer. Jour. Bot. 13:646-705.

9 KUNKEL, L. O.

1931. Studies on aster yellows in some new host plants. Boyce Thompson Inst. Contrib. 3:85-123.

10 MCKAY, M. B.

1928. The curly top disease. Seed World 23:38, 48, 72.

11 PRIODE, C. N.

1928. Further studies on the ringspot disease of tobacco. Amer. Jour. Bot. 15: 88-93.

12 Severin, H. H. P.

1927. Crops naturally infected with sugar beet curly-top. Science 66:137-138.

13 Severin, H. H. P.

1928. Transmission of tomato yellows, or curly top of the sugar beet, by Eutettix tenellus (Baker). Hilgardia 3(10):251-274.

14 Severin, H. H. P.

1929. Yellows disease of celery, lettuce, and other plants, transmitted by Cicadula sexnotata (Fall.). Hilgardia 3(18):543-582.

15 SeVERIN, H. H. P.

1929. Additional host plants of eurly top. Hilgardia 3(20):595-636.

16 Severin, H. H. P.

1929. Curly-top symptoms on the sugar beet. California Agr. Exp. Sta. Bul. 465: 1-35. 
17 Severin, H. H. P., AND J. H. Freitag.

1933. List of ornamental flowering plants naturally infected with eurly top or yellows diseases in California. Plant Disease Reporter 17:1-2. [Issued by the U.S. Dept. Agr. Bur. Plant Indus.]

18 Severin, H. H. P., ANd C. F. Henderson.

1928. Some host plants of eurly top. Hilgardia 3(18):339-392.

19 Sмiтн, K. M.

1931. Thrips tabaci Lind. as a vector of plant virus disease. Nature [London] $127(3214): 852-853$.

20 SмIтн, K. M.

1931. Studies on potato virus diseases. VIII. On a ringspot virus affecting solanaceous plants. Ann. Appl. Biol. 18:1-15.

21 SмIтн, K. M.

1932. Studies on plant virus diseases. XI. Further experiments with a ringspot virus: its identification with spotted wilt of the tomato. Ann. Appl. Biol. $19: 305-330$.

22 Wingard, S. A.

1928. Host and symptoms of ringspot, a virus disease of plants. Jour. Agr. Research 37:127-153.

23 Wingard, S. A., AND J. Godkin.

1924. Tobaceo diseases in Virginia and their control. Virginia Agr. Ext. Bul. $90: 1-31$. 

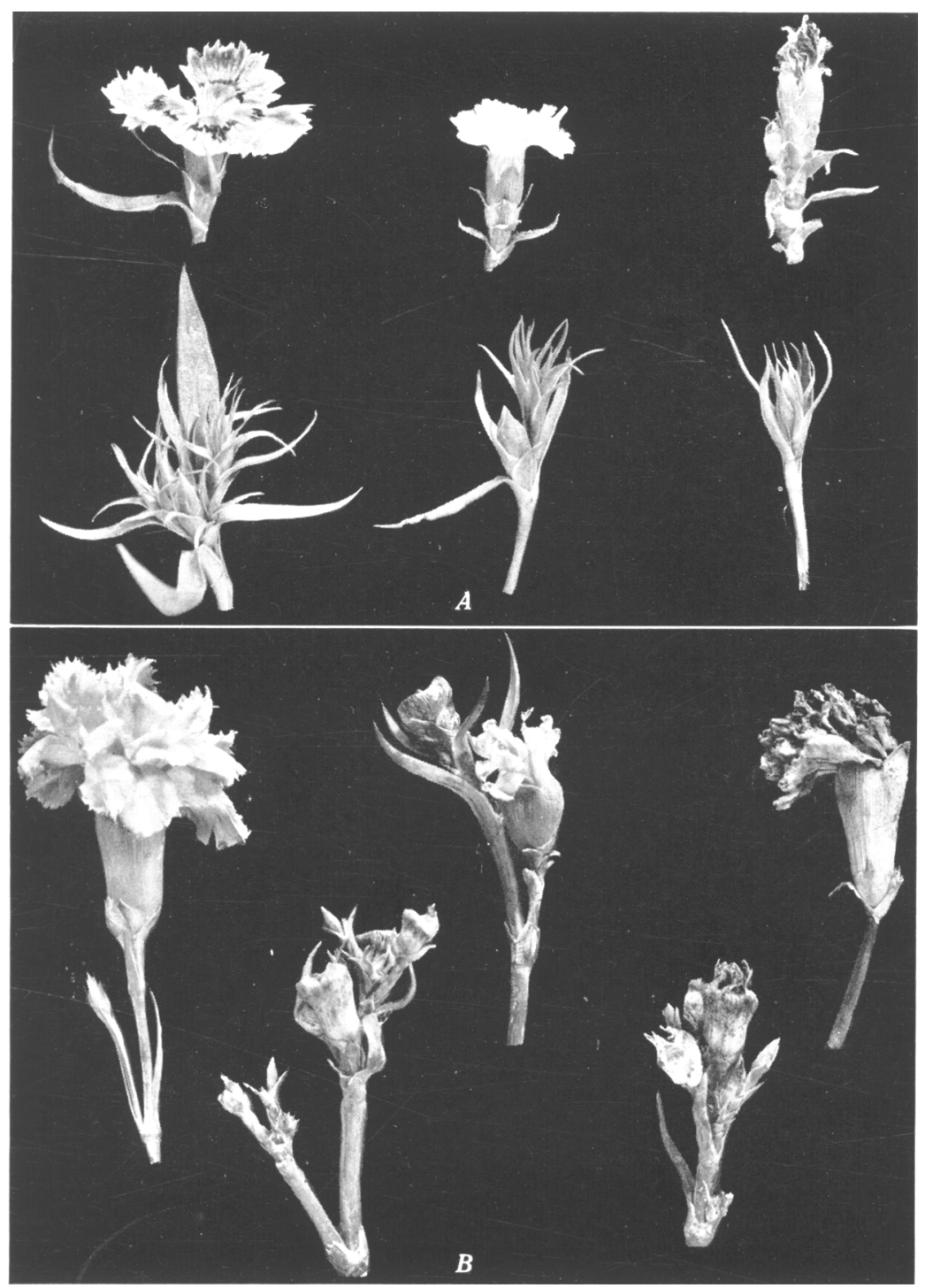

Plate 1. A, Grass pink (Dianthus plumarius) : upper row left, normal flower from healthy plant; center, dwarfed flower, white in color instead of red or rose-colored; right, flower with dried petals, from plant naturally infected with curly top; lower row, flower buds with numerous bracts (Keyes, San Joaquin Valley, November 9, 1932). B, Carnation (Dianthus caryophyllus ): upper row left, normal flower from healthy plant; center, dwarfed flower: right, flower with dried petals, from plant naturally infected with curly top; lower row, dried bell-shaped flower buds with no petals (Keyes, San Joaquin Valley, November 9, 1932 ). 

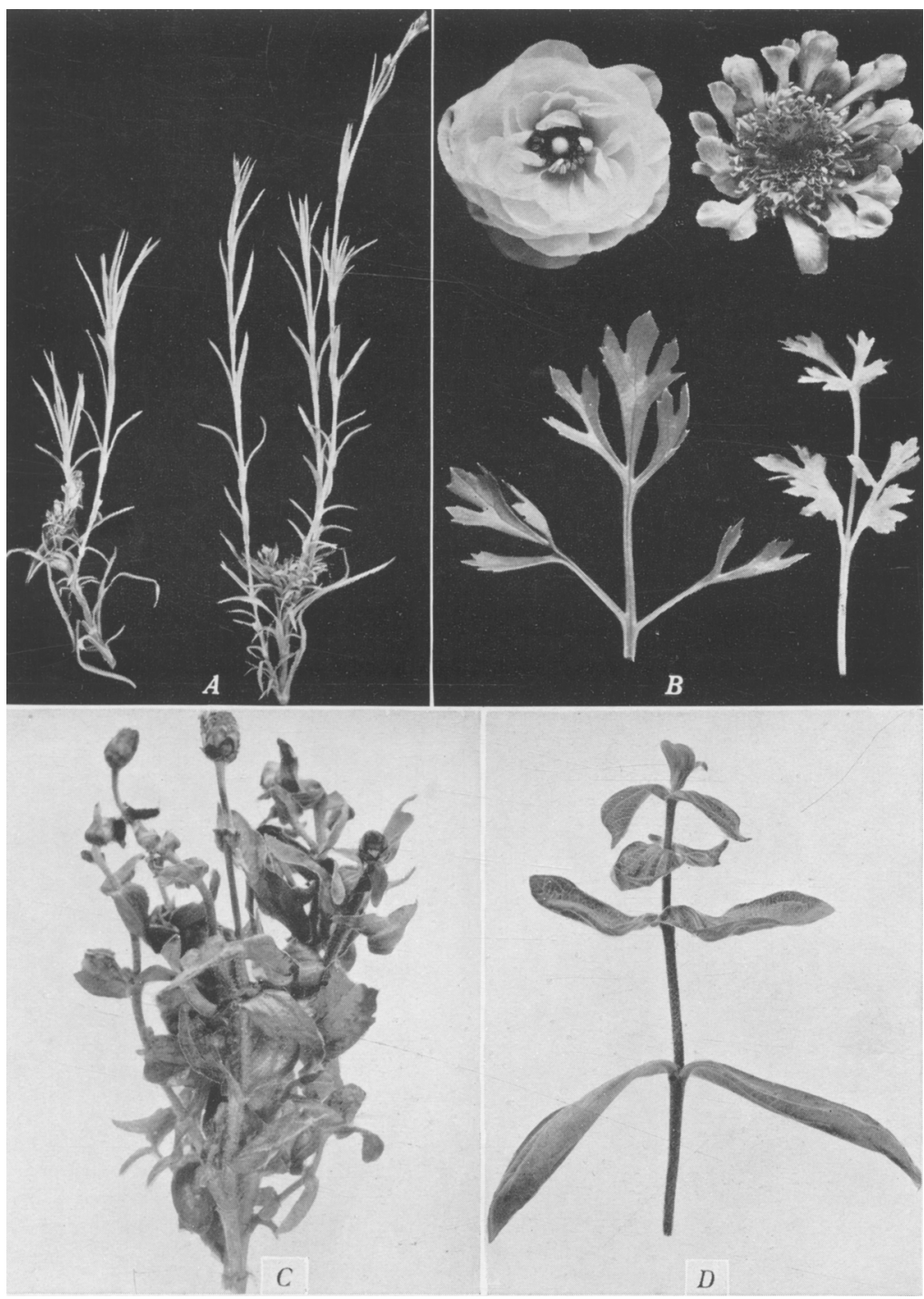

Plate 2. A, Carnation (Dianthus caryophyllus): branches showing secondary shoots with clusters of dwarfed leaves, and apparently healthy stems with normal leaves from a plant naturally infected with curly top (Keyes, San Joaquin Valley, November 9,1932 ). $B$, Turban and Persian buttercups (Ranunculus asiaticus): upper left, normal flower from healthy plant; upper right, abnormal flower from a diseased plant showing petals reduced in size; lower left, normal leaf from healthy plant; lower right, chlorotic leaf from a diseased plant (Carlsbad, San Diego County, March 17, 1933, courtesy of L. W. Massey), $C$, Common zinnia (Zinnia elegans): plant naturally infected with curly top showing secondary shoots (Fresno, San Joaquin Valley, November 9, 1932). D, Common zinnia (Zinnia elegans): apical end of branch from a plant experimentally infected with curly top, showing cleared or transparent veinlets on the youngest leaves. 


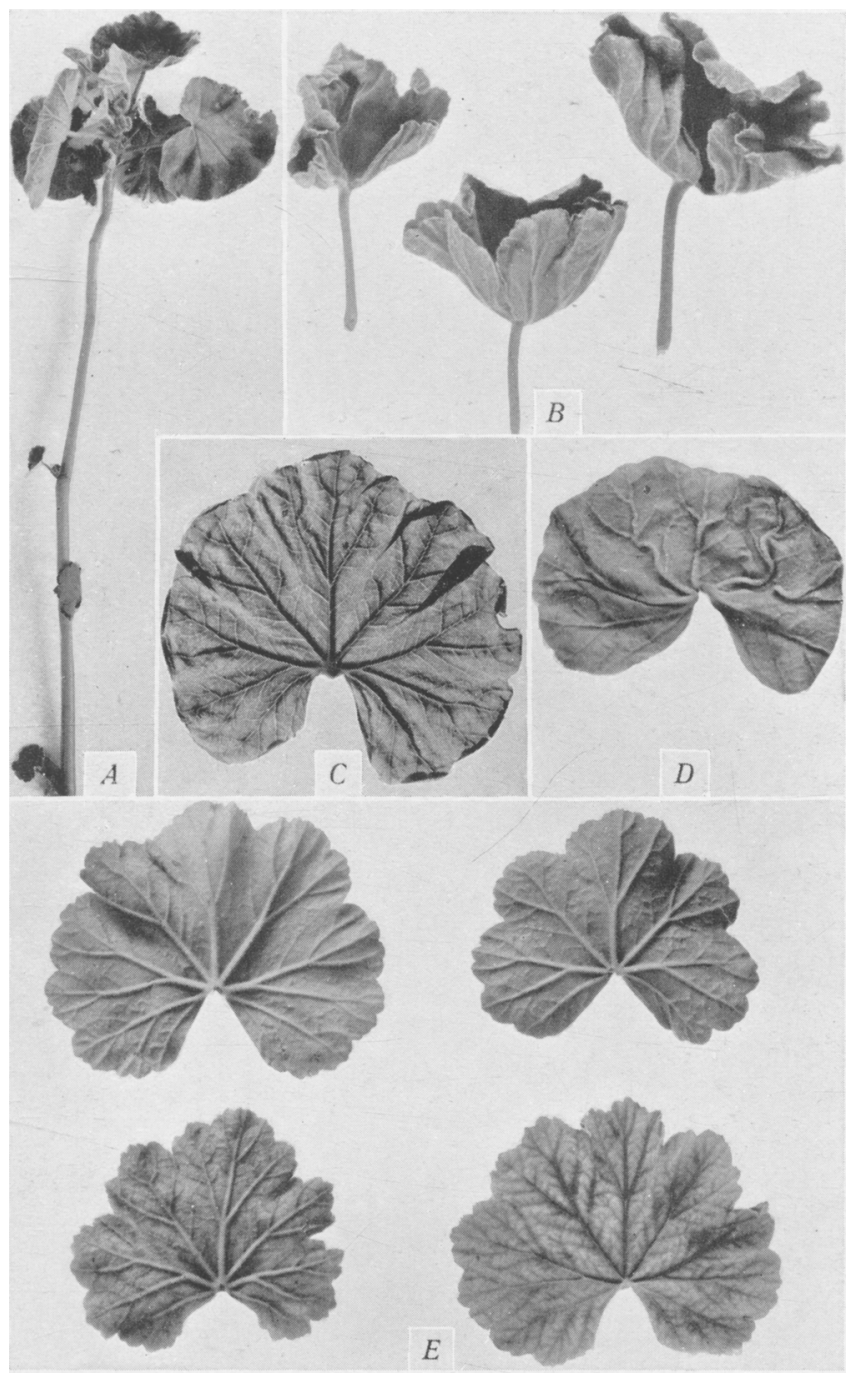

Plate 3. Fish geranium (Pelargonium hortorum): A, Cluster of apical leaves on old branch with dwarfed leaves at the nodes (Dos Palos, San Joaquin Valley, April 10, 1933). $B$, Leaves showing inward rolling of the margin or cupping of the blades (Los Banos, San Joaquin Valley, November 8,1932 ). $C$, Leaf showing cleared or transparent veinlets (Dos Palos, San Joaquin Valiey, April 10,1933). D, Leaf showing sinuous veins (Dos Palos, San Joaquin Valley, April 10, 1933). E, Upper row, leaves from plant naturally infected with curly top, showing small elevations resembling tiny warts; lower row, leaves showing chlorotic areas between the veins (Dos Palos, San Joaquin Valley, November 8, 1933). 

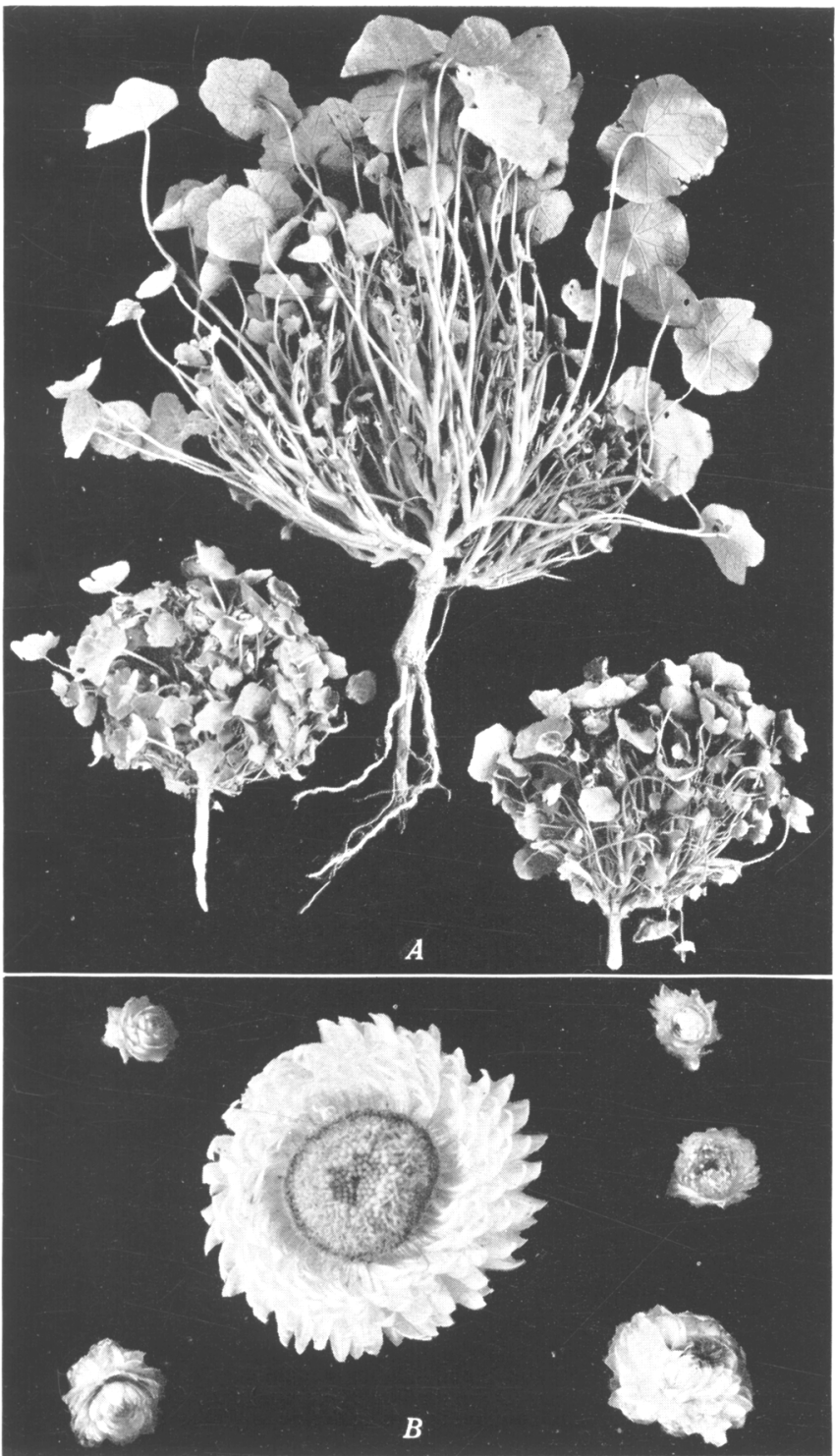

Plate 4. A, Dwarfed type of common nasturtium (Tropaeolum majus): two stunted and one large plant apparently naturally infected with curly top, showing numerous secondary shoots (Davis, Sacramento Valley, November 1, 1932). $B$, Strawflower (Helichysum bracteatum) : center, normal flower from a healthy plant; grouped around it are five dwarfed flowers from a plant naturally infected with curly top (Greenfield, Salinas Valley, November 3,1932 ). 